SILVA, Carolina Schauffert Ávila da; LEITE, José Rubens Morato. Pagamento por Serviços Ambientais no contexto da Política Nacional de Resíduos: A Caso da Projeto de Lei de Florianópolis. Revista Eletrônica Direito e Política, Programa de Pós-Graduação Stricto Sensu em Ciência Jurídica da UNIVALI, Itajaí, v.13, n.1, 10 quadrimestre de 2018. Disponível em: www.univali.br/direitoepolitica - ISSN 1980-7791

\title{
PAGAMENTO POR SERVIÇOS AMBIENTAIS NO CONTEXTO DA POLÍTICA NACIONAL DE RESÍdUOS: A CASO DO PROJETO DE LEI DE FLORIANÓPOLIS
}

\author{
PAYMENT FOR ENVIRONMENTAL SERVICES IN THE CONTEXT OF THE NATIONAL \\ WASTE POLICY: THE FLORIANOPOLIS PROJECT
}

\section{Carolina Schauffert Ávila da Silva \\ José Rubens Morato Leite ${ }^{2}$}

\begin{abstract}
SÚMARIO: Introdução; 1. Economia e o meio ambiente: externalidades ambientais; 2. Remanejamento Fiscal de Fritjof Capra: tributos como instrumentos de proteção ambiental; 3. Pagamento por Serviços Ambientais Urbanos dos resíduos sólidos; 4. Os serviços ambientais urbanos a partir de uma Política Pública; Considerações Finais; Referência das fontes citadas.
\end{abstract}

\section{RESUMO}

Fritjof Capra, em sua obra "As Conexões Ocultas: ciência para uma vida sustentável" propõe o chamado "remanejamento fiscal", onde através da concessão de incentivos, os contribuintes adotarão estratégias de projetos ecológicos. O trabalho analisará o remanejamento fiscal de Capra, através do método dedutivo, e a sua aplicação através do Pagamento por Serviços Ambientais Urbanos, relativos aos resíduos sólidos, caracterizando forte instrumento na defesa do meio ambiente. O ensaio objetiva trazer um enfoque teórico, reflexivo e proativo da proposta que objetiva a introdução de normas premiais, estabelecendo um instrumento fora do sistema tradicional da tutela administrativa de comando e controle, estabelecendo um instrumento econômico de pagamento por serviços ambientais voltados as pessoas vulneráveis da

\footnotetext{
1 Mestranda em Direito, Estado e Sociedade no Programa de Pós-graduação em DireitoPPGD/UFSC. Florianópolis, Santa Catarina, Brasil. carolavilasilva@gmail.com

2 Professor Titular dos cursos de Graduação e Pós-graduação em Direito da Universidade Federal de Santa Catarina - UFSC; Pós-Doutor pelo Center of Environmental Law, Macquarie University - Sydney - Austrália; Doutor em Direito Ambiental pela UFSC, com estágio de doutoramento na Faculdade de Direito da Universidade de Coimbra; mestre em Direito pela University College London; Membro e Consultor da IUCN - The World Conservation Union Comission on Environmental Law (Steering Commitee); Presidente do Instituto "O Direito por um Planeta Verde" - 2011-2016; coordenador do Grupo de Pesquisa Direito Ambiental e Ecologia Política na Sociedade de Risco, do CNPq. Bolsista e Consultor Ad Hoc do CNPq e Fapesc. Prêmio Pesquisador Destaque da Universidade Federal de Santa Catarina. 2011. Florianópolis, Santa Catarina, Brasil. moratoleite@yahoo.com.br
} 
SILVA, Carolina Schauffert Ávila da; LEITE, José Rubens Morato. Pagamento por Serviços Ambientais no contexto da Política Nacional de Resíduos: A Caso da Projeto de Lei de Florianópolis. Revista Eletrônica Direito e Política, Programa de Pós-Graduação Stricto Sensu em Ciência Jurídica da UNIVALI, Itajaí, v.13, n.1, 10 quadrimestre de 2018. Disponível em: www.univali.br/direitoepolitica - ISSN 1980-7791

sociedade, como foco da política de resíduos a nível do âmbito local da Capital do Estado de Santa Catarina.

Palavras-Chave: Economia Ambiental; Extrafiscalidade; Resíduos sólidos; Pagamento por Serviços Ambientais Urbanos

\section{ABSTRACT}

Fritjof Capra, in his book "The Hidden Connections: Science for a Sustainable Life" proposes the so-called "fiscal relocation", where through the granting of incentives, taxpayers will adopt ecological project strategies. The work will analyze Capra's fiscal relocation, through the deductive method, and its application through the Payment for Urban Environmental Services, related to solid waste, characterizing a strong instrument in the defense of the environment. The objective of this essay is to provide a theoretical, reflexive and proactive approach to the proposal that aims at the introduction of standards, establishing an instrument outside the traditional system of administrative supervision of command and control, establishing an economic instrument for payment for environmental services aimed at vulnerable people Society, as the focus of the waste policy at the local level of the Capital of the State of Santa Catarina

Keywords: Environmental economy; Extrafiscality; Solid Waste; Payment for Urban Environmental Services

\section{INTRODUÇÃO}

Diante do cenário hodierno vivido pelo Planeta referente à grave crise ambiental observada na sociedade atual, a busca por novas soluções e caminhos que objetivem frear a celeridade verificada nos processos de degradação resultantes do crescimento econômico se faz urgente e incessante.

De fato, as catástrofes ambientais sempre se viram presentes. Em que pese a crise ambiental seja um assunto relativamente recente, suas causas (reais ou presumidas) foram vistas de diferentes maneiras ao longo da história.

Com o advento da sociedade de risco de Ulrich Beck, os riscos provenientes do modelo econômico adotado até então passam a ser ameaças reais, tendo em vista a apropriação consumista e individualista verificada.

Assim, a sociedade atual é marcada pela proliferação de riscos e incertezas oriundas do próprio desenvolvimento tecnológico e econômico. Dentre tais riscos, encontram-se os riscos ambientais. 
SILVA, Carolina Schauffert Ávila da; LEITE, José Rubens Morato. Pagamento por Serviços Ambientais no contexto da Política Nacional de Resíduos: A Caso da Projeto de Lei de Florianópolis. Revista Eletrônica Direito e Política, Programa de Pós-Graduação Stricto Sensu em Ciência Jurídica da UNIVALI, Itajaí, v.13, n.1, 10 quadrimestre de 2018. Disponível em: www.univali.br/direitoepolitica - ISSN 1980-7791

O desenvolvimento tem sido realizado às custas da natureza, sem uma visão prospectiva. Assim, a crise ambiental que caracteriza o chamado Antropoceno, ou seja, a nova era geológica em que a Terra está dominada pelo ser humano, é um problema com dimensão intergeracional e interespécies, que coloca em risco a estabilidade do Planeta.

Os desafios observados na atualidade são dotados de imprevisão e ambivalência concernentes à sociedade de risco, tendo como ponto de partida uma perspectiva ética, bem como o princípio da responsabilidade e a formulação do paradigma da justiça ecológica, a garantirem o direito fundamental a um meio ambiente ecologicamente equilibrado como orientador de toda a atividade econômica.

Publicada em 24 de maio de 2015, o Papa Francisco, na sua Carta Encíclica "Laudato Si" demonstra a grande preocupação moderna com a preservação e manutenção do meio ambiente. Com o título "Sobre o cuidado da Casa Comum", o Papa divulga aos Bispos e, por meio destes a todos os fiéis, seus pensamentos a respeito da situação da humanidade e do mundo, fazendo considerações teológicas e/ou filosóficas a respeito do cenário mundial atual.

Em seu texto, o Papa Francisco afirma que, embora a mudança faça parte da dinâmica dos sistemas complexos, a velocidade que hoje é imposta pelas ações humanas frente ao desejado crescimento econômico contrasta com a lentidão natural da evolução biológica. Soma-se a isto o fato relativo ao grave problema de que os objetivos desta mudança rápida e constante não estão necessariamente orientados ao bem comum e para um desenvolvimento humano sustentável. A mudança, segundo o Papa, é algo desejável, mas torna-se preocupante quando se transforma em deterioração do mundo e da qualidade de vida de grande parte da humanidade ${ }^{3}$.

A crise ambiental vivida atualmente está intrinsecamente relacionada a economia, uma vez que seus valores visam sempre a majoração da produção e consequentemente do consumo.

3 Papa Francisco. Carta Encíclica Laudato Si "Sobre o cuidado da Casa Comum. Disponível em <https://w2.vatican.va/content/francesco/pt/encyclicals/documents/papa-

francesco_20150524_enciclica-laudato-si.html>. Acesso em 30 de maio de 2017. 
SILVA, Carolina Schauffert Ávila da; LEITE, José Rubens Morato. Pagamento por Serviços Ambientais no contexto da Política Nacional de Resíduos: A Caso da Projeto de Lei de Florianópolis. Revista Eletrônica Direito e Política, Programa de Pós-Graduação Stricto Sensu em Ciência Jurídica da UNIVALI, Itajaí, v.13, n.1, 10 quadrimestre de 2018. Disponível em: www.univali.br/direitoepolitica - ISSN 1980-7791

Diante todo este cenário, o objetivo do presente trabalho é analisar a interconexão e interdisciplinaridade que a proteção mais eficaz do meio ambiente exige, através do estudo do remanejamento fiscal proposto pelo teórico Fritjof Capra, para a aplicação de normas indutoras de comportamentos no âmbito da justiça ambiental, visando a promoção do incentivo a proteção do meio ambiente, frente a realidade econômica mundial.

Através da extrafiscalidade ambiental, é possível estimular condutas que sejam ecologicamente corretas, coibindo paralelamente práticas poluentes. Assim, o presente trabalho fará uma análise do papel do tributo como promotor da sustentabilidade, confirmando que, uma tributação bem estruturada, poderá servir de instrumento jurídico orientador para a maior eficácia da promoção do viés ambiental no Planeta.

A abordagem teórica do modelo de remanejamento de Capra conduz ao estímulo de políticas públicas voltadas à proteção ambiental no caso concreto. Desta forma, com o escopo de trazer resultados reais e que consigam atingir a mesma velocidade verificada nos processos de degradação relativos ao crescimento econômico feroz, a ideia é a aplicação da extrafiscalidade direta ao contribuinte, impulsionando comportamentos humanos para ao fim ambiental almejado.

Assim, tendo em vista uma das maiores preocupações modernas, utilizar-se-á como alvo os resíduos sólidos, analisando-se o Projeto de Lei que versa sobre a instituição de Pagamento por Serviços Ambientais Urbanos, voltados aos catadores de lixo reciclável ${ }^{4}$.

O tema justifica-se tendo em vista a sua contemporaneidade. Diz respeito a renovação das teorias econômicas clássicas e visa trazer novo alento a discussão dos tributos como instrumento à disposição do Poder Público para o alcance dos fins ambientais propostos.

Desta forma, diante da discussão que se propõe, denota-se que o estudo tem enfoque metodológico teórico e prático, com a teoria relacionada à proteção

\footnotetext{
4 Projeto de Lei de autoria do Vereador Marcos José de Abreu "Marquito", em tramitação junto à Câmara Municipal de Florianópolis/SC.
} 
SILVA, Carolina Schauffert Ávila da; LEITE, José Rubens Morato. Pagamento por Serviços Ambientais no contexto da Política Nacional de Resíduos: A Caso da Projeto de Lei de Florianópolis. Revista Eletrônica Direito e Política, Programa de Pós-Graduação Stricto Sensu em Ciência Jurídica da UNIVALI, Itajaí, v.13, n.1, 10 quadrimestre de 2018. Disponível em: www.univali.br/direitoepolitica - ISSN 1980-7791

ambiental e a prática voltada à análise de projeto de lei que pode trazer resultados reais na busca da manutenção do ecossistema sadio.

Pretende-se trazer à tona, no âmbito dos resíduos sólidos, o tema da tributação ambiental com o intuito de aprofundar o estudo dos alcances da extrafiscalidade tributária como uma das possíveis respostas ao uso inconsciente da natureza, capaz de promover inclusive uma consciência ambiental voltada a sustentabilidade do meio ambiente à presente e às futuras gerações.

\section{ECONOMIA E O MEIO AMBIENTE: EXTERNALIDADES AMBIENTAIS}

Denota-se que a crise ambiental vivida está ligada à economia e seus valores, os quais buscam o incremento dos meios de produção e consumo. Pautada na visão econômica tradicional, surgida na segunda metade do século XVIII, a sociedade atual evolui no tempo baseada na ideia de que tal evolução se dá de forma infinita, uma vez que o meio ambiente estaria apto a conceber o fornecimento de recursos de maneira ilimitada. Desta forma, suplanta-se a ideia de que o Planeta possui condições de suportar a degradação que o crescimento econômico exige ${ }^{5}$.

No pós-Revolução Industrial, a visão mecanicista do crescimento econômico que dominou o mundo desenvolveu um grande fascínio pelas máquinas. Desta forma, a Economia também foi concebida como uma máquina. Nas palavras de Giorgia Sena Martins "máquina perfeita, que poderia, teoricamente, funcionar de maneira incessante, sem necessitar de combustível, nem gerar resíduos que fossem dignos de nota no âmbito da teoria econômica"6.

Ocorre que tal fato não retrata a realidade do Planeta e tem demonstrado efeitos que não eram os pretendidos quando do domínio do pensamento industrial.

5 MARTINS, Giorgia Sena. Norma Ambiental: Complexidade e concretização. 2013. 411 p. Dissertação (Mestrado) - Universidade Federal de Santa Catarina, Centro Ciências Jurídicas, Programa de Pós-Graduação em Direito, Florianópolis, 2013. Disponível em: <http://www.bu.ufsc.br/teses/PDPC1106-D.pdf> Acesso em 22 de maio de 2017. p. 33.

$6 \quad$ MARTINS, Giorgia Sena. Norma Ambiental: Complexidade e concretização. p. 33. 
SILVA, Carolina Schauffert Ávila da; LEITE, José Rubens Morato. Pagamento por Serviços Ambientais no contexto da Política Nacional de Resíduos: A Caso da Projeto de Lei de Florianópolis. Revista Eletrônica Direito e Política, Programa de Pós-Graduação Stricto Sensu em Ciência Jurídica da UNIVALI, Itajaí, v.13, n.1, 10 quadrimestre de 2018. Disponível em: www.univali.br/direitoepolitica - ISSN 1980-7791

Desta forma, fica evidente que o crescimento infinito afirmado pela visão econômica tradicional não é compatível com o ponto de vista ambiental?.

A partir dos anos 60 e 70 do século $X X$, coincidentemente no cerne de uma crise econômica mundial relativa ao petróleo, é que a Economia demonstrará, pela primeira vez, grande preocupação quanto à diminuição da crescente depredação dos recursos naturais ${ }^{8}$.

Em tal cenário, a Economia Neoclássica passou a expandir instrumentos que autorizavam considerar a natureza. Neste aspecto, intitulou-se de "Economia Neoclássica Ambiental" ou simplesmente "Economia Ambiental" a pretensão dessa corrente de incorporar o tema "natureza" na função de produção, acreditando, contudo, que uma "combinação ótima dos fatores de produção segue sendo o principal fator de progresso da humanidade" ${ }^{\prime \prime}$.

De acordo com Carlos Monteiro, a Economia e a Ecologia são disciplinas que tem uma origem etimológica comum. A primeira deriva das palavras gregas oikos (casa) e nomos (regras, gestão). A segunda origina-se das palavras oikos (casa) e logos (estudo). Assim, pode-se afirmar que a Economia é a disciplina que cuida da gestão da casa, enquanto a Ecologia é a ciência que ocupa do estudo da casa $^{10}$.

Diante da magnitude da atual crise ambiental, exige-se um ponto de convergência entre as duas disciplinas. Na era do Antropoceno, Economia e Ecologia devem estar mais interligadas em uma rede de causas e efeitos. Desta forma, a situação ambiental atual exige que a lógica do sistema econômico seja inserida como subsistema ao sistema da natureza, ou seja, na biosfera ${ }^{11}$.

\footnotetext{
7 MARTINS, Giorgia Sena. Norma Ambiental: Complexidade e concretização. p. 33.

8 FOLADORI, Guillermo. Limites do Desenvolvimento Sustentável. Campinas: Unicamp, 2001. p. 141.

9 LUSTOSA Peter H.; Maria Cecília; VINHA, Valéria da. (org.). Economia do Meio Ambiente. Rio de Janeiro: Elsevier, 2003. p. 76.
}

10 MONTERO, Carlos Eduardo Peralta. Tributação Ambiental: Reflexões sobre a introdução da variável ambiental no sistema tributário. São Paulo: Saraiva, 2014. p. 115.

11 MONTERO, Carlos Eduardo Peralta. Tributação Ambiental: Reflexões sobre a introdução da variável ambiental no sistema tributário. p. 115. 
SILVA, Carolina Schauffert Ávila da; LEITE, José Rubens Morato. Pagamento por Serviços Ambientais no contexto da Política Nacional de Resíduos: A Caso da Projeto de Lei de Florianópolis. Revista Eletrônica Direito e Política, Programa de Pós-Graduação Stricto Sensu em Ciência Jurídica da UNIVALI, Itajaí, v.13, n.1, 10 quadrimestre de 2018. Disponível em: www.univali.br/direitoepolitica - ISSN 1980-7791

A Economia Ambiental Neoclássica nasce como uma tentativa de abordar os problemas ambientais dentro da lógica de mercado. Ou seja, a natureza é internalizada nas contas desta teoria enquanto a busca pela manutenção e expansão do modelo produtivo baseado no crescimento permanece. Assim, visa trazer equilíbrio entre a superexploração dos recursos naturais e a necessidade de se continuar buscando a melhoria da qualidade de vida humana por meio do processo produtivo ${ }^{12}$.

Ensina Carlos Monteiro que a economia do meio ambiente, em sentido amplo, surgiu com a finalidade de analisar como o sistema econômico pode configurar incentivos que promovem a degradação da natureza e, em contrapartida, como podem ser criados novos incentivos para que os agentes econômicos respeitem o meio ambiente ${ }^{13}$. Assim, a economia ecológica se formou como campo de estudo transdisciplinar que atraiu ecólogos sistêmicos e economistas dissidentes.

De acordo com Maurício de Carvalho Amazonas, a Economia Ambiental teve origem em dois subsídios básicos: a chamada "economia da poluição", que se deteve nos "outputs" indesejáveis despejados pelas atividades produtivas no meio ambiente, a exemplo da contaminação das águas, ar, solo; e a "economia dos recursos naturais", que teve como objeto os "inputs", ou seja, os recursos naturais como fonte de matérias-primas e na logística do seu esgotamento ${ }^{14}$.

Face a um ponto de vista econômico, a degradação ambiental envolve um problema referente a alocação adequada dos recursos ambientais. Isto se dá pelo fato de os recursos do nosso planeta serem limitados, e a apropriação deles

12 POPE, KAMILA. Understanding planned obsolescence: unsustainability through production, consumption a waste generation. London: Kogan Page Limited, 2017, p. 102-103.

13 MONTERO, Carlos Eduardo Peralta. Tributação Ambiental: Reflexões sobre a introdução da variável ambiental no sistema tributário. São Paulo: Saraiva, 2014. p. 116.

14 AMAZONAS, Maurício de Carvalho. Desenvolvimento Sustentável e a teoria econômica: o debate conceitual nas perspectivas neoclássica, institucionalista e da economia ecológica. In: NOBRE, Marcos; AMAZONAS, Maurício de Carvalho (org.) Desenvolvimento Sustentável: A institucionalização de um Conceito. Brasília: Edições IBAMA, 2002. p. 109 
SILVA, Carolina Schauffert Ávila da; LEITE, José Rubens Morato. Pagamento por Serviços Ambientais no contexto da Política Nacional de Resíduos: A Caso da Projeto de Lei de Florianópolis. Revista Eletrônica Direito e Política, Programa de Pós-Graduação Stricto Sensu em Ciência Jurídica da UNIVALI, Itajaí, v.13, n.1, 10 quadrimestre de 2018. Disponível em: www.univali.br/direitoepolitica - ISSN 1980-7791

por parte dos agentes econômicos se dar de forma que não atenda aos critérios equitativos, nem à capacidade de tolerância do nosso entorno ambiental ${ }^{15}$.

O mercado, guiado pelas suas próprias leis, é inábil para satisfazer as demandas dos seres humanos sem causar prejuízos ao meio ambiente. Os agentes econômicos têm como objetivo o lucro, ignorando os benefícios que são oriundos da exploração do meio ambiente e os custos sociais que o uso dos recursos naturais representa: "o valor do meio ambiente e as consequências derivadas desta utilização são desconsideradas no mundo dos interesses econômicos"16.

Leff ensina que os economistas passaram então a denominar "externalidade" do sistema econômico o conjunto de situações problemáticas que se verificam fora do alcance do entendimento da própria teoria do processo econômico, a qual tem tido destaque sobre as formas de organização social e de intervenção na natureza ${ }^{17}$.

Nas palavras de Nusdeo, as externalidades correspondem aos custos e benefícios circulando externamente ao mercado, vale dizer, que se quedam incompensados pois, para eles, o mercado não consegue imputar um preço ${ }^{18}$.

Neste escopo, as falhas do mercado são o que dão origem as externalidades ambientais. Tais externalidades podem ser positivas ou negativas, sendo, grosso modo, os efeitos produzidos pelos processos de produção ou de consumo que prejudicam ou beneficiam terceiros que não pertencem à transação. Ou seja, "tratam-se dos custos ou benefícios criados pelas diversas atividades econômicas

15 AMAZONAS, Maurício de Carvalho. Desenvolvimento Sustentável e a teoria econômica: o debate conceitual nas perspectivas neoclássica, institucionalista e da economia ecológica. p. 124

16 AMAZONAS, Maurício de Carvalho. Desenvolvimento Sustentável e a teoria econômica: o debate conceitual nas perspectivas neoclássica, institucionalista e da economia ecológica. p. 125.

17 LEFF, Enrique. Discursos sustentáveis. Tradução de Silvana Cobucci Leite. São Paulo: Cortez, 2010. p. 20

18 NUSDEO, Fabio. Curso de economia: introdução ao direito economico. São Paulo: Revista dos Tribunais, 1997, p. 177. 
SILVA, Carolina Schauffert Ávila da; LEITE, José Rubens Morato. Pagamento por Serviços Ambientais no contexto da Política Nacional de Resíduos: A Caso da Projeto de Lei de Florianópolis. Revista Eletrônica Direito e Política, Programa de Pós-Graduação Stricto Sensu em Ciência Jurídica da UNIVALI, Itajaí, v.13, n.1, 10 quadrimestre de 2018. Disponível em: www.univali.br/direitoepolitica - ISSN 1980-7791

que, não sendo devidamente internalizados, circulam externamente ao mercado"19.

De acordo com Tupiassu, a externalidade ambiental é um dos pontos mais relevantes de uma análise econômico-fiscal imprescindível à proteção ao meio ambiente. Isto ocorre uma vez que, é através do conceito de externalidade que se entende a função do Estado, dos entes privados e da sociedade no alcance do bem-estar geral, por uma necessidade da própria estrutura econômica, sendo a base dos princípios de economia ambiental ${ }^{20}$.

A visão utilitarista do meio ambiente, imperiosa na sociedade de risco, a qual o considera como algo à disposição dos seres humanos de forma infinita, colabora para que grande parte dos problemas ambientais atuais tenha uma estreita ligação com as externalidades ambientais negativas ${ }^{21}$.

Na economia ecológica, enxerga-se a economia como embutida no ecossistema (ou, de modo mais exato, na percepção social cambiante da história do ecossistema). A economia está, portanto, embutida na estrutura dos direitos de propriedade sobre os recursos e serviços ambientais, na distribuição social do poder e da renda, nas estruturas sociais de gênero, classe ou casta social22.

É necessário, portanto, que os poderem públicos intervenham para limitar as externalidades ambientais, através da otimização de sua função ambiental, numa ação integrada com os entes privados e com os cidadãos. A realização deste objetivo resvala, notadamente, pela utilização de um modo mais racional e substancial, fundamentado nos princípios contidos na Constituição, dos próprios

\footnotetext{
19 MONTERO, Carlos Eduardo Peralta. Tributação Ambiental: Reflexões sobre a introdução da variável ambiental no sistema tributário. p. 126.

20 TUPIASSU, Lise Vieira da Costa. Tributação Ambiental: A utilização de instrumentos econômicos e fiscais na implementação do direito ao meio ambiente saudável. Rio de Janeiro: Renovar, 2006. p. 66.
}

21 MONTERO, Carlos Eduardo Peralta. Tributação Ambiental: Reflexões sobre a introdução da variável ambiental no sistema tributário. São Paulo: Saraiva, 2014. p. 127.

22 DALY, H. (ed). 1973. Toward a Steady-State Economy. W. H. Freeman, San Francisco. 
SILVA, Carolina Schauffert Ávila da; LEITE, José Rubens Morato. Pagamento por Serviços Ambientais no contexto da Política Nacional de Resíduos: A Caso da Projeto de Lei de Florianópolis. Revista Eletrônica Direito e Política, Programa de Pós-Graduação Stricto Sensu em Ciência Jurídica da UNIVALI, Itajaí, v.13, n.1, 10 quadrimestre de 2018. Disponível em: www.univali.br/direitoepolitica - ISSN 1980-7791

mecanismos existentes para a implementação de políticas públicas, dentre os quais se sobressai a concessão de benefícios fiscais e financeiros ${ }^{23}$.

\section{REMANEJAMENTO FISCAL DE FRITJOF CAPRA: TRIBUTOS COMO INSTRUMENTOS DE PROTEÇÃO AMBIENTAL}

Por meio da Constituição Federal de 1988, o Estado detém a obrigação de proteger e manter o meio ambiente. Deve, portanto, intervir nas atividades econômicas com o intuito de colaborar na correção das deficiências do mercado, auxiliando a propiciar uma distribuição equânime dos recursos que observem a sustentabilidade do meio ambiente ${ }^{24}$.

Carlos Monteiro ensina que, no viés econômico, o Estado apropria-se de um novo papel, o papel de um Estado Regulador, ligado à atividade econômica para guiála aos valores e princípios constitucionais, visando o desenvolvimento humano e social de forma sustentável ${ }^{25}$.

A coordenada intervenção do Estado sobre o domínio econômico se transforma no fundamental meio de implementação das políticas públicas, voltadas para a dinamicidade dos acontecimentos sociais, devendo estar apta a corrigir as novas distorções que se apresentam²6.

Assim, esta intervenção no processo de interação entre o Poder Estatal e a sociedade configura-se como a consequência das transformações históricas, culturais e ideológicas vinculadas ao desenvolvimento do sistema econômico, que implicam, por conseguinte, numa evolução das prestações asseguradas pelo Poder Público aos cidadãos, de modo que as sucessivas funções historicamente

\footnotetext{
23 TUPIASSU, Lise Vieira da Costa. Tributação Ambiental: A utilização de instrumentos econômicos e fiscais na implementação do direito ao meio ambiente saudavel. Rio de Janeiro: Renovar, 2006. p. 73.

24 MONTERO, Carlos Eduardo Peralta. Tributação Ambiental: Reflexões sobre a introdução da variável ambiental no sistema tributário. p. 137.

25 MONTERO, Carlos Eduardo Peralta. Tributação Ambiental: Reflexões sobre a introdução da variável ambiental no sistema tributário. p. 138.

26 MONTERO, Carlos Eduardo Peralta. Tributação Ambiental: Reflexões sobre a introdução da variável ambiental no sistema tributário. p. 32.
} 
SILVA, Carolina Schauffert Ávila da; LEITE, José Rubens Morato. Pagamento por Serviços Ambientais no contexto da Política Nacional de Resíduos: A Caso da Projeto de Lei de Florianópolis. Revista Eletrônica Direito e Política, Programa de Pós-Graduação Stricto Sensu em Ciência Jurídica da UNIVALI, Itajaí, v.13, n.1, 10 quadrimestre de 2018. Disponível em: www.univali.br/direitoepolitica - ISSN 1980-7791

assumidas pelo Estado vem sendo sempre determinadas pelos interesses e conflitos socioeconômicos nele assumidos ${ }^{27}$.

Desta maneira, ainda que por regra as atividades econômicas estejam eivadas pelo princípio da liberdade de iniciativa, o Estado possui recursos no que diz respeito ao papel normativo e regulador, podendo atingir as atividades econômicas através do planejamento, dos incentivos e da fiscalização ${ }^{28}$.

Neste sentido, destaca-se o papel do tributo na atualidade, o qual é tido como um dos instrumentos econômicos mais importantes para a proteção ambiental, através da chamada finalidade extrafiscal ${ }^{29}$.

Em que pese a relação conturbada entre os contribuintes e os tributos, não há como desvincular a história da humanidade com a arrecadação, vez que dependente uma da outra. Segundo Braga Monteiro ${ }^{30}$, a história da humanidade se confunde com a história dos tributos. E é interessante isso, pois igual às mudanças sociais, políticas e econômicas que a humanidade passou, o objetivo do tributo e o meio pelo qual ele era arrecadado nunca foi estático - mudou com o passar dos tempos.

Nas palavras de Oliveira e Horvath ${ }^{31}$, a principal função da tributação é a arrecadação fiscal. Assim, fiscalidade é quando os objetivos que presidiram a instituição do tributo são simplesmente aqueles de abastecer os cofres públicos. Em complemento, os professores Derzi e Coelho ${ }^{32}$ definem que tal poder de tributar do Estado, justificado pela necessidade deste de obter recursos para a

27 MONTERO, Carlos Eduardo Peralta. Tributação Ambiental: Reflexões sobre a introdução da variável ambiental no sistema tributário. p. 32.

28 MONTERO, Carlos Eduardo Peralta. Tributação Ambiental: Reflexões sobre a introdução da variável ambiental no sistema tributário. p. 139.

29 MONTERO, Carlos Eduardo Peralta. Tributação Ambiental: Reflexões sobre a introdução da variável ambiental no sistema tributário. p. 168.

30 MONTEIRO, José Carlos Braga. A Relação da História da Humanidade e os Tributos. Disponível em http://www.portaltributario.com.br/artigos/relacao-da-historia-humanidade-etributos.htm. 2014. Acesso em 23 de maio de 2017.

31 OliveirA, R.; Horvath, E. Manual de direito financeiro. São Paulo: Ed. Revista dos Tribunais, 2002, p. 213.

32 DERZI, Misabel de Abreu Machado; COELHO, Sacha Calmon Navarro. Do Imposto sobre a propriedade predial e territorial urbana. São Paulo: Saraiva, 1982, p. 31. 
SILVA, Carolina Schauffert Ávila da; LEITE, José Rubens Morato. Pagamento por Serviços Ambientais no contexto da Política Nacional de Resíduos: A Caso da Projeto de Lei de Florianópolis. Revista Eletrônica Direito e Política, Programa de Pós-Graduação Stricto Sensu em Ciência Jurídica da UNIVALI, Itajaí, v.13, n.1, 10 quadrimestre de 2018. Disponível em: www.univali.br/direitoepolitica - ISSN 1980-7791

consecução de seus fins, em prol da comunidade, implica nas contribuições dos cidadãos, decorrentes diretamente da Constituição.

Nesse sentido, o poder de tributar está na origem do Ente Político, uma vez que, visando à arrecadação fiscal, permitiu que os homens passassem a constituir uma sociedade, gerindo-a através de um governo e financiando-a, estabelecendo uma relação clara entre governante e governados.

E justamente por referir-se à construção do bem-comum da sociedade que cabe à tributação o poder de restringir a capacidade econômica do indivíduo. O poder de tributar justifica-se pela prevalência do bem da coletividade em detrimento dos interesses individuais, pois, na falta do Estado, não haveria garantia nem mesmo à propriedade privada e à preservação da vida ${ }^{33}$.

Neste ínterim, pode a legislação de um tributo ser elaborada com providências no sentido de prestigiar certas situações (ou, ao contrário, desprestigiar outras), tidas como social, política ou economicamente valiosas, às quais o legislador dispensa tratamento mais confortável ou menos gravoso (ou, em outras situações, mais gravoso). A esta nova função dos tributos, denomina-se extrafiscalidade.

Tupiassu leciona que, ao lado de sua função principal de angariar fundos para a consecução dos fins estatais, os tributos podem ser utilizados para direcionar a conduta dos contribuintes, sendo dotados, portanto, de fins extrafiscais ${ }^{34}$.

Por meio da função denominada de extrafiscalidade, portanto, é que o Estado utiliza-se do tributo como um instrumento de coordenação que lhe permite intervir na atividade econômica com o objetivo de alcançar determinados resultados almejados pela sociedade ${ }^{35}$.

\footnotetext{
33 DERZI, Misabel de Abreu Machado; COELHO, Sacha Calmon Navarro. Do Imposto sobre a propriedade predial e territorial urbana. p. 214.

34 TUPIASSU, Lise Vieira da Costa. Tributação Ambiental: A utilização de instrumentos econômicos e fiscais na implementação do direito ao meio ambiente saudavel. p. 118.

35 TUPIASSU, Lise Vieira da Costa. Tributação Ambiental: A utilização de instrumentos econômicos e fiscais na implementação do direito ao meio ambiente saudavel. p. 179.
} 
SILVA, Carolina Schauffert Ávila da; LEITE, José Rubens Morato. Pagamento por Serviços Ambientais no contexto da Política Nacional de Resíduos: A Caso da Projeto de Lei de Florianópolis. Revista Eletrônica Direito e Política, Programa de Pós-Graduação Stricto Sensu em Ciência Jurídica da UNIVALI, Itajaí, v.13, n.1, 10 quadrimestre de 2018. Disponível em: www.univali.br/direitoepolitica - ISSN 1980-7791

Neste mesmo sentido, Machado ${ }^{36}$ preceitua que na atualidade, dificilmente um tributo é utilizado apenas como instrumento de arrecadação. Daí surge a extrafiscalidade dos tributos, que constitui função além daquela primordial, qual seja, a de arrecadação. Ligada a valores constitucionais, pode decorrer de isenções, benefícios fiscais, progressividade de alíquotas, finalidades especiais, entre outros institutos criadores de diferenças entre os indivíduos.

Corrobora Barros Carvalho, ao afirmar que não existe no ordenamento jurídico brasileiro um tributo que realize somente a fiscalidade ou somente a extrafiscalidade, vez que ambas as funções subsistem e, por vezes, uma predomina sobre a outra ${ }^{37}$.

Desta forma, surgem possibilidades quanto à tributação ambiental, onde a função extrafiscal dos tributos contribui de modo eficiente ao mudar a carga fiscal dos chamados "comportamentos bons", ligados à preservação, para os "comportamentos ruins", como a poluição e a devastação dos recursos naturais.

A tributação, assim, cumpriria sua função extrafiscal, se estruturando de modo a tornar completamente inconveniente o comportamento ambiental danoso e prestigiar o comportamento desejado. O legislador poderá gerar incentivo a atividades sustentáveis ou coibir atividades danosas ao meio ambiente, através da concessão de benefícios fiscais frente ao cumprimento de determinadas ações que visem à preservação.

Conforme ensinamentos de Leão ${ }^{38}$, a defesa do meio ambiente tem gerado forte influência no campo do Direito Tributário, afirmando que cada vez mais verificase a "ecologização" deste ramo do Direito, a qual decorre de uma política ambiental suscitada pela oneração das atividades poluentes, as quais geram prejuízos ambientais, em detrimento das normas que visam apenas a concessão de benefícios fiscais para aqueles que contribuem com a preservação ambiental.

\footnotetext{
36 MACHADO, Hugo de Brito. Curso de Direito Constitucional Tributário. $2^{a}$ ed. São Paulo: Malheiros, 2015, p. 435.

37 CARVALHO, Paulo de Barros. Curso de direito tributário. 16. ed. São Paulo: Saraiva, 2011, p. 249-250.

38 LEÃO, Martha Toribio. Controle da Extrafiscalidade - Série Doutrina Tributária v. XVI. São Paulo: Quartier Latin, 2015, p. 71
} 
SILVA, Carolina Schauffert Ávila da; LEITE, José Rubens Morato. Pagamento por Serviços Ambientais no contexto da Política Nacional de Resíduos: A Caso da Projeto de Lei de Florianópolis. Revista Eletrônica Direito e Política, Programa de Pós-Graduação Stricto Sensu em Ciência Jurídica da UNIVALI, Itajaí, v.13, n.1, 10 quadrimestre de 2018. Disponível em: www.univali.br/direitoepolitica - ISSN 1980-7791

Ainda no campo da interdisciplinaridade exigida pelo Direito Ambiental para a busca de uma proteção do meio ambiente mais efetiva, Schoueri39 afirma que a proteção ambiental é um vasto campo a aplicação de normas com cunho extrafiscal, denominadas pelo autor de "normas indutoras", vez que induzem comportamentos de seus contribuintes, já que permite a internalização dos custos ambientais gerados pela degradação ocorrida, imputando-se aos agentes poluidores a responsabilidade pela integração do valor referente às medidas de proteção ambiental nos seus custos de produção.

Ademais, quanto ao tema, Voigt ${ }^{40}$ aduz que o desenvolvimento sustentável só pode ser alcançado no contexto do Estado de Direito, exigindo uma cooperação internacional justa, eficaz e disposições nacionais de governação e uma política ambiental clara.

Fritjof Capra, físico, teórico e escritor, é conhecido mundialmente por desenvolver trabalhos voltados primordialmente à educação ecológica ${ }^{41}$.

Em seu livro intitulado "As Conexões Ocultas: ciência para uma vida sustentável", Capra desenvolveu uma compreensão sistêmica e unificada que compõe as dimensões biológica, cognitiva e social da vida, lecionando que a vida, em todos os seus níveis, é interligada por redes complexas.

Segundo o autor, verifica-se, neste novo século, a ocorrência de dois fenômenos específicos que gerarão efeitos significativos sobre o bem-estar e os modos de vida da humanidade. Ambos esses fenômenos têm por base as redes da vida e envolvem tecnologias novas. O primeiro é a ascensão do capitalismo global; o segundo é a criação de comunidades sustentáveis baseadas na alfabetização ecológica e na prática do projeto ecológico. Enquanto que o capitalismo global é

39 SCHOUERI, Luiz Eduardo. Normas Tributárias Indutoras e Intervenção Econômica. Rio de Janeiro: Forense, 2005, p. 97.

40 VOIGT, Christina. The principle of sustainable development: integration and ecological integrity. Rule of law for nature: New Dimensions and Ideas in Environmental Law. Cambridge University Press, 2013. p. 146.

41 WIKIPEDIA. Disponível em https://pt.wikipedia.org/wiki/Fritjof_Capra. Acesso em 03 de julho de 2017. 
SILVA, Carolina Schauffert Ávila da; LEITE, José Rubens Morato. Pagamento por Serviços Ambientais no contexto da Política Nacional de Resíduos: A Caso da Projeto de Lei de Florianópolis. Revista Eletrônica Direito e Política, Programa de Pós-Graduação Stricto Sensu em Ciência Jurídica da UNIVALI, Itajaí, v.13, n.1, $1^{\circ}$ quadrimestre de 2018. Disponível em: www.univali.br/direitoepolitica - ISSN 1980-7791

feito de redes eletrônicas onde correm fluxos financeiros e fluxos de informações, o projeto ecológico trata das redes ecológicas de fluxos energéticos e materiais ${ }^{42}$. Assim, enquanto o objetivo da economia global é o de elevar ao máximo a riqueza e o poder de suas elites; o objetivo do projeto ecológico é o de elevar ao máximo a sustentabilidade da teia da vida ${ }^{43}$.

Ocorre que, atualmente essas duas propostas encontram-se em rota de colisão. Segundo Capra, a forma atual do capitalismo global é insustentável dos pontos de vista social e ecológico:

O chamado 'mercado global' nada mais é do que uma rede de máquinas programadas para atender a um único princípio fundamental: o de que o ganhar dinheiro deve ter precedência sobre os direitos humanos, a democracia, a proteção ambiental ${ }^{44}$.

Entretanto, os valores humanos podem mudar, vez que são leis naturais. As mesmas redes eletrônicas nas quais correm os fluxos financeiros e de informação podem ser programadas de acordo com outros valores. A questão principal não é a tecnologia, mas a política. O grande desafio do século XXI é a implementação de uma mudança no sistema de valores que está por trás da economia global, de modo a torná-lo compatível com as exigências da dignidade humana e da sustentabilidade ecológica ${ }^{45}$.

$\mathrm{Na}$ sociedade capitalista atual, o valor central relativo aos ganhos financeiros caminha de mãos dadas com a exaltação do consumo material. Todas as mensagens publicitárias através da mídia em massa reforçam a ilusão das pessoas de que a acumulação de bens materiais é o caminho que leva à felicidade, o próprio objetivo da nossa vida ${ }^{46}$.

42 CAPRA, Fritjof. As conexões ocultas: ciência para uma vida sustentável. Tradução Marcelo Brandão Cipolla. Cultrix: São Paulo, 2002. p. 252.

43 CAPRA, Fritjof. As conexões ocultas: ciência para uma vida sustentável. p. 252

44 CAPRA, Fritjof. As conexões ocultas: ciência para uma vida sustentável. p. 252.

45 CAPRA, Fritjof. As conexões ocultas: ciência para uma vida sustentável. p. 252

46 CAPRA, Fritjof. As conexões ocultas: ciência para uma vida sustentável. p. 252. 
SILVA, Carolina Schauffert Ávila da; LEITE, José Rubens Morato. Pagamento por Serviços Ambientais no contexto da Política Nacional de Resíduos: A Caso da Projeto de Lei de Florianópolis. Revista Eletrônica Direito e Política, Programa de Pós-Graduação Stricto Sensu em Ciência Jurídica da UNIVALI, Itajaí, v.13, n.1, 10 quadrimestre de 2018. Disponível em: www.univali.br/direitoepolitica - ISSN 1980-7791

Desta forma, diante de todo o cenário que se coloca, Fritjof Capra afirma que a transição para um futuro sustentável já não é um problema técnico, nem conceitual, mas um problema de valores e de vontade política.

O estudioso aduz ainda que as políticas necessárias para dar suporte aos projetos ecológicos resumem-se a:

Uma mistura de concorrência de mercado e regulamentação, com a instituição de impostos ambientais para corrigir as distorções do mercado; subsídios temporários para amparar a entrada das fontes renováveis no mercado; e a eliminação dos subsídios ocultos dados às fontes convencionais ${ }^{47}$.

Neste contexto, a extrafiscalidade dos tributos insere-se na ordem do dia como instrumento apto a tornar mais eficaz o dever constitucional de manutenção do meio ambiente equilibrado à presente e às futuras gerações, através da instituição dos impostos ambientais, que trazem em seu bojo a indução de comportamentos desejáveis à preservação do meio ambiente.

De acordo com a linha de pensamento de Capra, o sistema de impostos vigentes na sociedade contemporânea impõem um pesado fardo naquilo que se entende possuir maior relevância na vida dos seres humanos, tais como nos empregos, economias, investimentos, em sentido oposto àquilo que se considera nocivo, o que não é de fato taxado, como a poluição, a degradação ambiental, o esgotamento de recursos, etc. Segundo o físico, necessário se faz a inversão do sistema, ou seja, ao invés de taxar a renda e os salários, é primordial a taxação de atividades que atinjam e causem a degradação dos recursos não-renováveis ${ }^{48}$. Assim, essa reforma fiscal, que antes era denominada de "reforma fiscal ecológica", passou a ser identificada por Fritjof Capra como "remanejamento fiscal". De acordo com o modelo proposto pelo físico, o remanejamento fiscal não alteraria em nada as receitas do governo:

Isso significa que certos impostos seriam acrescentados a produtos, serviços, materiais e formas de energia já existentes de modo que o preço deles refletisse melhor o seu custo verdadeiro; e, ao mesmo tempo, uma quantidade

47 CAPRA, Fritjof. As conexões ocultas: ciência para uma vida sustentável. p. 253.

48 CAPRA, Fritjof. As conexões ocultas: ciência para uma vida sustentável. p. 254. 
SILVA, Carolina Schauffert Ávila da; LEITE, José Rubens Morato. Pagamento por Serviços Ambientais no contexto da Política Nacional de Resíduos: A Caso da Projeto de Lei de Florianópolis. Revista Eletrônica Direito e Política, Programa de Pós-Graduação Stricto Sensu em Ciência Jurídica da UNIVALI, Itajaí, v.13, n.1, 10 quadrimestre de 2018. Disponível em: www.univali.br/direitoepolitica - ISSN 1980-7791

equivalente de impostos seria eliminada das rendas e salário ${ }^{49}$.

Neste sentido, o processo de remanejamento fiscal proposto deve ser implementado de modo à encorajar uma inovação no mundo globalizado, eliminando aos poucos os hábitos de consumo marcados pelo desperdício, verificado na sociedade atual ${ }^{50}$.

O que se busca com o presente artigo é apresentar um formato de benefício fiscal que seja baseado no projeto de remanejamento fiscal apresentado por Capra, com objetivos semelhantes ao do modelo, porém que inclua em seu objetivo a concretização de comportamentos pró-ambiente, que sejam induzidos através da arrecadação proveniente do tributo denominado Taxa de Resíduos Sólidos.

\section{PAGAMENTO POR SERVIÇOS AMBIENTAIS URBANOS DOS RESÍDUOS SÓLIDOS}

Os hábitos de consumo derivados do desenvolvimento econômico atual traduzem-se em uma excessiva produção de resíduos que, pela sua qualidade e quantidade, constitui a causa de uma das mais importantes disfunções ambientais. Todas as etapas do gerenciamento dos resíduos sólidos, que englobam desde a sua geração até a sua disposição final exigem soluções conjuntas entre governantes e a sociedade, visto que o volume dos resíduos cresce em proporções geométricas, enquanto a solução para a gestão aumenta em escala aritmética ${ }^{51}$.

Desde tempos remotos, o homem desfez-se do lixo que produzia, de uma forma muito conveniente: abandonando-o em qualquer local. Os primeiros problemas referentes ao acúmulo de resíduos surgiram com a fixação do Homem, quando

\footnotetext{
49 CAPRA, Fritjof. As conexões ocultas: ciência para uma vida sustentável. p. 255.

50 CAPRA, Fritjof. As conexões ocultas: ciência para uma vida sustentável. p. 255.

51 TROTTA, Pasquale. A gestão de resíduos sólidos em Portugal. Disponível em http://www.inovarse.org/sites/default/files/T11_0350_2173_7.pdf. Acesso em 03 de julho de 2017.
} 
SILVA, Carolina Schauffert Ávila da; LEITE, José Rubens Morato. Pagamento por Serviços Ambientais no contexto da Política Nacional de Resíduos: A Caso da Projeto de Lei de Florianópolis. Revista Eletrônica Direito e Política, Programa de Pós-Graduação Stricto Sensu em Ciência Jurídica da UNIVALI, Itajaí, v.13, n.1, 10 quadrimestre de 2018. Disponível em: www.univali.br/direitoepolitica - ISSN 1980-7791

este começa a viver em comunidades e a quantidade de lixo aumenta, sendo indispensável encontrar soluções para a eliminação dos resíduos que produz ${ }^{52}$.

Demajorovic identificou nos países desenvolvidos, nos últimos vinte e cinco anos, três fases que mostram a evolução dos modelos de gestão de resíduos sólidos ${ }^{53}$ :

Na chamada primeira fase, a prioridade era somente a disposição dos resíduos, sem que fosse levado em consideração qualquer iniciativa que objetivasse à redução dos resíduos em outras etapas do processo produtivo. Como consequência, houve o crescimento acelerado do volume final de resíduos a serem dispostos proporcionalmente à expansão da produção e do consumo. A maior parte dos resíduos passou a ser encaminhada para aterros sanitários e incineradores ${ }^{54}$.

$\mathrm{Na}$ segunda fase, verificou-se que a reciclagem dos materiais passou a ser considerada meta prioritária na política de gestão de resíduos. Estabeleceram-se novas relações entre consumidores finais e produtores, e entre distribuidores e consumidores, para garantir ao menos o reaproveitamento de parte dos resíduos. A reciclagem, feita em diferentes etapas do processo produtivo, levou ao crescimento mais lento do consumo de recursos naturais e do volume de resíduos a serem dispostos, graças ao reaproveitamento de parte dos resíduos que, durante a $1^{\text {a }}$ fase, estaria destinada aos aterros sanitários e incineradores. Em contrapartida, aumentaram as críticas quanto à falta de uma política específica para tratamento de resíduos tóxicos e à expansão das exportações desses resíduos para disposição final em países em desenvolvimento ${ }^{55}$.

Por sua vez, ocorrida no final da década de 80 , a terceira fase da evolução dos modelos de gestão de resíduos sólidos marca o estabelecimento de novas

\footnotetext{
52 PHILIPPI JR, A. Sistema de resíduos sólidos: coleta e transporte no meio urbano. 1979. Dissertação (Mestrado) Departamento de Saúde Ambiental da Faculdade de Saúde Pública da USP, São Paulo, 1979. p. 147

53 DEMAJOROVIC J. A evolução dos modelos de gestão de resíduos sólidos e seus instrumentos. Cadernos FUNDAP; 1996. p. 87

54 DEMAJOROVIC J. A evolução dos modelos de gestão de resíduos sólidos e seus instrumentos. p. 87.

55 DEMAJOROVIC J. A evolução dos modelos de gestão de resíduos sólidos e seus instrumentos. p. 88
} 
SILVA, Carolina Schauffert Ávila da; LEITE, José Rubens Morato. Pagamento por Serviços Ambientais no contexto da Política Nacional de Resíduos: A Caso da Projeto de Lei de Florianópolis. Revista Eletrônica Direito e Política, Programa de Pós-Graduação Stricto Sensu em Ciência Jurídica da UNIVALI, Itajaí, v.13, n.1, $1^{\circ}$ quadrimestre de 2018. Disponível em: www.univali.br/direitoepolitica - ISSN 1980-7791

prioridades, verificada especialmente nos países desenvolvidos. A atenção passa a concentrar-se na redução do volume de resíduos, desde o início do processo produtivo e em todas as etapas da cadeia produtiva. Assim, antes de diminuir a produção de determinados bens, passa a ser prioritário impedir que sejam gerados. Em vez de buscar a reciclagem, propõe-se a reutilização ${ }^{56}$.

Atualmente, são diretrizes prioritárias de políticas de gestão de resíduos: evitar ou, nos casos em que não for possível, diminuir a produção de resíduos; reutilizá-los ou, quando não for possível, reciclá-los; utilizar a energia neles contida; torná-los inertes, antes da disposição final.

O custeio da gestão dos resíduos sólidos, relativos à coleta, transporte, tratamento e destinação final é feito através da cobrança, pelos Municípios, da taxa de resíduos sólidos.

As taxas tratam-se de tributos com grande abrangência estrutural. Como destaca Tupiassu, as taxas sobre serviços, como é o caso dos resíduos sólidos (coleta de lixo), podem perfeitamente ter um caráter incentivador quando houver um sistema de graduação de alíquotas estruturado de acordo com o grau de poluição apresentado pelo resíduo ${ }^{57}$.

Neste sentido, autorizado pela legislação pátria vigente e utilizando-se da interconexão entre a Filosofia e o Direito, o objetivo do trabalho é apresentar uma ideia que reflita sobre a indução de comportamentos benéficos ao meio ambiente, baseado no modelo de remanejamento fiscal de Fritjof Capra, relacionada com a aplicação da extrafiscalidade nos resíduos sólidos, para a implantação pelo Poder Público de concessão de incentivos econômicos, denominados Pagamentos por Serviços Ambientais (PSA), aos coletores de lixo reciclável, gerando cumulativamente oportunidades de empregos e proteção ambiental.

\footnotetext{
56 DEMAJOROVIC J. A evolução dos modelos de gestão de resíduos sólidos e seus instrumentos. p. 88.

57 TUPIASSU, Lise Vieira da Costa. Tributação Ambiental: A utilização de instrumentos econômicos e fiscais na implementação do direito ao meio ambiente saudável. 141.
} 
SILVA, Carolina Schauffert Ávila da; LEITE, José Rubens Morato. Pagamento por Serviços Ambientais no contexto da Política Nacional de Resíduos: A Caso da Projeto de Lei de Florianópolis. Revista Eletrônica Direito e Política, Programa de Pós-Graduação Stricto Sensu em Ciência Jurídica da UNIVALI, Itajaí, v.13, n.1, 10 quadrimestre de 2018. Disponível em: www.univali.br/direitoepolitica - ISSN 1980-7791

Para tanto, faz-se necessário esclarecer conceitos abordados no cerne do projeto em questão.

Primeiramente, os denominados "serviços ambientais" ou também chamados de "serviços ecossistêmicos", são os benefícios que as pessoas obtêm da natureza direta ou indiretamente, através dos ecossistemas, a fim de sustentar a vida no planeta $^{58}$.

Desta forma, serviço ambiental é a capacidade da natureza de fornecer qualidade de vida e comodidades, ou seja, garantir que a vida exista para todos e com qualidade. Assim, tem-se que a natureza trabalha, ou presta serviços, para a manutenção da vida e de seus processos e estes serviços realizados pela natureza são conhecidos como serviços ambientais ${ }^{59}$.

Da mesma forma, o termo "serviço ambiental urbano" surge em razão dos serviços urbanos que têm interface com a questão ambiental. Nesse sentido, os serviços ambientais urbanos surgiriam em contexto próximo ao dos serviços de saneamento ambiental, estando relacionados à gestão de resíduos sólidos urbanos.

Embora não tenham um preço estabelecido, os serviços ambientais são muito valiosos para o bem-estar e a própria sobrevivência da humanidade, pois deles dependem as atividades humanas. A continuidade ou manutenção desses serviços necessita, diretamente, da conservação e preservação ambiental, além de práticas que minimizem os impactos das ações humanas sobre o ambiente.

Daí surge o conceito de Pagamento por Serviços Ambientais (PSA), definido por Wunder como uma transação voluntária, na qual um serviço ambiental bem

58 (o) Eco. Disponível em <http://www.oeco.org.br/dicionario-ambiental/28158-o-que-saoservicos-ambientais/> Acesso em 21 de julho de 2017.

59 Unidades de Conservação no Brasil. Disponível em <https://uc.socioambiental.org/servicosambientais/o-que-sao-servicos-ambientais> Acesso em 21 de julho de 2017. 
SILVA, Carolina Schauffert Ávila da; LEITE, José Rubens Morato. Pagamento por Serviços Ambientais no contexto da Política Nacional de Resíduos: A Caso da Projeto de Lei de Florianópolis. Revista Eletrônica Direito e Política, Programa de Pós-Graduação Stricto Sensu em Ciência Jurídica da UNIVALI, Itajaí, v.13, n.1, 10 quadrimestre de 2018. Disponível em: www.univali.br/direitoepolitica - ISSN 1980-7791

definido é adquirido por um "comprador" de um "provedor", sob a condição de garantia da provisão deste serviço ${ }^{60}$.

Assim, o Pagamento por Serviços Ambientais é um tipo de incentivo econômico pago àquele que gerir ecossistemas visando melhorar o fluxo de serviços ambientais que prestam ${ }^{61}$.

Os sistemas de PSA objetivam mudar a estrutura de incentivos econômicos a que os agentes estão submetidos, para que aumente a atratividade de atividades econômicas que ajudam a produzir serviços ecossistêmicos para a sociedade em detrimento de atividades não sustentáveis. Um sistema de PSA deve prover renda extra para agentes que façam uso mais sustentável dos recursos naturais, seguindo o princípio do "protetor-recebedor". Simetricamente, pelo lado do financiamento, é proposta a aplicação de um princípio de "beneficiário-pagador"62.

Em resumo, a ideia central dos sistemas de PSA é permitir que os beneficiários de um serviço ambiental possam fazer pagamentos diretos, contratuais e condicionados aos produtores de serviços ambientais, em retorno à adoção de práticas que asseguram a conservação e a restauração dos ecossistemas ${ }^{63}$.

Além do foco na integridade dos ecossistemas, muitas iniciativas de PSA que vêm sendo implantadas têm também como objetivo diminuir a desigualdade social. Essas são iniciativas válidas, principalmente, no contexto de países muito desiguais, uma vez que existem importantes sinergias entre PSA e redução da pobreza, conforme já preconizado no modelo de remanejamento fiscal de Fritjof

60 SEVEN WUNDER apud SEVEN WUNDER et alli. Pagamento por Serviços Ambientais: Perspectivas para a Amazônia Legal. Brasília: MMA , 2009, p. 30-31.

61 FAO-Organização das Nações Unidas para a Agricultura. Disponível em <http://www.fao.org/Es/esa/pesal>

Acesso em 21 de juhlo de 2017

62 Relatório de Pesquisa sobre Pagamento por Serviços Ambientais Urbanos para Gestão de Resíduos Sólidos. Disponível em <http://www.mma.gov.br/estruturas/253/_arquivos/estudo_do_ipea_253.pdf> Acesso em 25 de julho de 2017.

63 WUNDER, S. Payments for environmental services: some nuts and bolts. Bogor Barat: Cifor, 2005 (Cifor Occasional Paper, n. 42). Disponível em: <http://www.cifor.cgiar.org/publications/pdf_files/OccPapers/OP-42. pdf>. Acesso em: 25 jul. 2017. 
SILVA, Carolina Schauffert Ávila da; LEITE, José Rubens Morato. Pagamento por Serviços Ambientais no contexto da Política Nacional de Resíduos: A Caso da Projeto de Lei de Florianópolis. Revista Eletrônica Direito e Política, Programa de Pós-Graduação Stricto Sensu em Ciência Jurídica da UNIVALI, Itajaí, v.13, n.1, 10 quadrimestre de 2018. Disponível em: www.univali.br/direitoepolitica - ISSN 1980-7791

Capra, quando os programas são bem desenhados e adequados às realidades locais ${ }^{64}$.

Tais sinergias podem ser resultantes tanto da transferência de recursos dos beneficiados pelos serviços ambientais para grupos mais pobres, como do estímulo a sua organização ou ainda do desenvolvimento de práticas de trabalho mais sustentáveis. Sendo assim, políticas de PSA não apenas melhorariam as condições dos recursos naturais e aumentariam a compreensão sobre o valor dos ecossistemas, mas também contribuiriam para o desenvolvimento econômico de grupos sociais específicos ${ }^{65}$.

Neste sentido, objetiva-se a instituição de Pagamento por Serviços Ambientais na gestão de resíduos sólidos, tema abordado no item a seguir.

\section{OS SERVIÇOS AMBIENTAIS URBANOS A PARTIR DE UMA POLITICA PÚBLICA}

De acordo com o projeto proposto, a Administração Pública Municipal de Florianópolis remunerará, mensalmente, as associações ou cooperativas de catadores de materiais recicláveis pelos serviços ambientais prestados na gestão do resíduo sólido urbano.

Uma vez que o Município mantém contrato com empresa terceirizada, o qual possui alto valor mensal, a ideia é a minoração deste gasto público referente ao serviço de limpeza, transporte e destinação final dos resíduos sólidos, com a consequente criação de serviços de cunho social, voltados à catação e reciclagem.

Esta diminuição do contrato firmado pelo Município justifica-se pois, com o incremento no serviço de reciclagem, o volume de resíduos a ser destinado aos aterros sanitários reduziria consideravelmente.

64 PAGIOLA, S.; ARCENAS, A.; PLATAIS, G. Can payments for environmental services help reduce poverty? An exploration of the issues and the evidence to date from Latin America. World Development, v. 33, n. 2, p. 237- 253, 2005.

65 KOSOY, N. et al. Payments for environmental services in watersheds: insights from a comparative study of three cases in Central America. Ecological Economics, v. 61, n. 2, p. 446-455, 2007. 
SILVA, Carolina Schauffert Ávila da; LEITE, José Rubens Morato. Pagamento por Serviços Ambientais no contexto da Política Nacional de Resíduos: A Caso da Projeto de Lei de Florianópolis. Revista Eletrônica Direito e Política, Programa de Pós-Graduação Stricto Sensu em Ciência Jurídica da UNIVALI, Itajaí, v.13, n.1, $1^{\circ}$ quadrimestre de 2018. Disponível em: www.univali.br/direitoepolitica - ISSN 1980-7791

O serviço prestado pelos aterros sanitários no Município de Florianópolis é feito através de contratação de serviço terceirizado, gestionado por empresa privada. Desta feita, além de trazer benefícios de ordem ambiental, o projeto objetiva a economia quanto aos gastos públicos referentes a esta contratação, preservando o erário. Desta forma, quanto menos material chegar ao aterro, menor será o custo municipal com os resíduos sólidos.

As diretrizes desta instituição do Pagamento por Serviço Ambiental Urbano são a valorização e o fortalecimento das associações e cooperativas de catadores de materiais recicláveis e o fomento à economia solidária; a valorização do trabalho socioambiental dos catadores de materiais recicláveis; a promoção do desenvolvimento ambiental, social e economicamente sustentável; o incremento da destinação e da disposição ambientalmente adequada dos resíduos sólidos urbanos e a redução gradativa da quantidade disposta em aterros sanitários.

Além disso, o projeto tem como finalidade a promoção da educação ambiental para o estímulo progressivo à separação doméstica dos resíduos, à coleta seletiva, à reciclagem e à compostagem.

Cria-se assim um estímulo à reciclagem solidária e coletiva, evitando a proliferação de doenças e problemas sanitários, ao mesmo tempo em que apoia reflexivamente os processos ecológicos sistêmicos. Indiretamente, o serviço causa a diminuição no uso dos recursos naturais de uso comum, uma vez que suplanta a reciclagem dos objetos descartados, que se acumulariam nos aterros, trazendo prejuízos de ordem ambiental, econômica e política. Assim, incrementando o reuso dos objetos que a priori não teriam mais utilização, desestimula a degradação dos recursos naturais coletivos.

A Lei Brasileira de Política Nacional de Resíduos Sólidos (Lei no 12.305, de 02 de agosto de 2010) trouxe grande novidade ao apresentar forte caráter social, estabelecendo prioridades quanto aos excluídos na concessão de benefícios que estimulem a função social da sociedade diante da criação de serviços aos catadores e daqueles que querem exercer cidadania solidaria. O artigo $8^{\circ}$ da lei traz como instrumento da Política Nacional de Resíduos Sólidos o incentivo à 
SILVA, Carolina Schauffert Ávila da; LEITE, José Rubens Morato. Pagamento por Serviços Ambientais no contexto da Política Nacional de Resíduos: A Caso da Projeto de Lei de Florianópolis. Revista Eletrônica Direito e Política, Programa de Pós-Graduação Stricto Sensu em Ciência Jurídica da UNIVALI, Itajaí, v.13, n.1, $1^{\circ}$ quadrimestre de 2018. Disponível em: www.univali.br/direitoepolitica - ISSN 1980-7791

criação e ao desenvolvimento de cooperativas ou de outras formas de associação de catadores de materiais reutilizáveis e recicláveis.

A lei traz em seu artigo 44 dispositivos referente à instituição de normas indutoras, cujo objetivo seja a concessão de incentivos fiscais e financeiros, respeitados os limites impostos pela Lei de Responsabilidade Fiscal.

Além disso, instituiu o sistema de logística reversa, por meio do qual exige dos fabricantes, importadores, distribuidores e comerciantes de agrotóxicos (seus resíduos e embalagens), pilhas, baterias, pneus, óleos lubrificantes (seus resíduos e embalagens), lâmpadas fluorescentes e produtos eletroeletrônicos o retorno dos produtos após o uso pelo consumidor, bem como a diminuição na produção de embalagem e a internalização do custo de sua produção, de forma independente do serviço público de limpeza urbana e de manejo dos resíduos sólidos.

Desta forma, a Lei de Política Nacional dos Resíduos Sólidos estabelece que todos fazem parte de uma cadeia sistêmica, salientando assim as necessidades de um país em desenvolvimento.

Em tempos de grave crise econômica acometida pelo País, a questão da exclusão social resta majorada e verifica-se a diminuição na concessão de oportunidades àqueles que se encontram à margem da sociedade.

O projeto volta suas prioridades ao incremento de empregos e ao estabelecimento de renda aos catadores, os quais encontram-se em situação de vulnerabilidade, religando o econômico ao social, relacionando adequadamente tais questões com o ambiental. Ademais, leva-se em consideração que os serviços prestados pelos catadores possuem alto grau de periculosidade, estando constantemente expostos a condições insalubres, envolvendo assim elevado risco laboral.

Assim, privilegia a inclusão social ao mesmo tempo em que traz um incremento à proteção dos recursos naturais e à indução à proteção ambiental coletiva, 
SILVA, Carolina Schauffert Ávila da; LEITE, José Rubens Morato. Pagamento por Serviços Ambientais no contexto da Política Nacional de Resíduos: A Caso da Projeto de Lei de Florianópolis. Revista Eletrônica Direito e Política, Programa de Pós-Graduação Stricto Sensu em Ciência Jurídica da UNIVALI, Itajaí, v.13, n.1, 10 quadrimestre de 2018. Disponível em: www.univali.br/direitoepolitica - ISSN 1980-7791

refletindo em todo ecossistema, majorando a resiliência urbana e a solidariedade face à sadia qualidade de vida.

Em síntese, o projeto vai além do âmbito puramente econômico, articulando o político e o social, a solidariedade e os vínculos de reciprocidade à atividade produtiva.

Nesse contexto, o PSA aparece como elemento novo, apontando para a ampliação da renda dos catadores e para a alteração na forma de inserção dos mesmos no mercado de recicláveis, através do incentivo às associações, aproximando-os mais da esfera estatal.

De modo geral, os catadores são identificados pela pobreza que os atinge, notadamente quando executam o seu trabalho informalmente ou de maneira individual. De acordo com o IPEA - Instituto de Pesquisa Econômica Aplicada, apenas $10 \%$ estariam organizados em cooperativas ou associações (IPEA, $2013)^{66}$.

Há, no entanto, entre os catadores organizados em cooperativas e associações, cenários diferentes, quando comparados aos catadores que atuam na informalidade. Segundo Damásio (2010a), em pesquisa realizada no Rio de Janeiro, com 219 catadores, a renda média observada foi de R\$519,859. Na região Sul, pesquisa desenvolvida pela UFRGS registrou renda média de R\$418,11 (2010). Em Minas Gerais, Silva (2007) registrou renda média de R\$ 492,0210. É importante notar que estas pesquisas dizem respeito a catadores organizados em cooperativas e associações. A atuação em aterros sanitários e nas ruas das cidades tende a reverter rendimentos menores aos catadores. Em 2010, em pesquisa que realizamos entre 59 catadores que trabalhavam no aterro da cidade de Arapiraca, registramos variação de renda mensal entre $R \$ 100,00$ e $\mathrm{R} \$$ 400,00. Em 2012, realizamos mais uma pesquisa, desta vez entre 40

\footnotetext{
66 Ao todo, haveria no Brasil, segundo levantamento do IPEA (2012), 800.000 catadores de materiais recicláveis, contingente compatível com a estimativa do Movimento Nacional de Catadores de Material Reciclável. Mas há outras estimativas: 500.000 (CÁRITAS, 2011; INSTITUTO PÓLIS, 2008) ou entre 300.000 e 1.000 .000 (CEMPRE, 2011).
} 
SILVA, Carolina Schauffert Ávila da; LEITE, José Rubens Morato. Pagamento por Serviços Ambientais no contexto da Política Nacional de Resíduos: A Caso da Projeto de Lei de Florianópolis. Revista Eletrônica Direito e Política, Programa de Pós-Graduação Stricto Sensu em Ciência Jurídica da UNIVALI, Itajaí, v.13, n.1, 10 quadrimestre de 2018. Disponível em: www.univali.br/direitoepolitica - ISSN 1980-7791

catadores de rua da cidade de Arapiraca, cuja renda média registrada foi de $\mathrm{R} \$ 250,00^{67}$.

A observação destes dados deixa entrever que o trabalho organizado de forma coletiva resulta em maior rendimento aos catadores, pois aumenta sua eficiência produtiva, em função da otimização da força de trabalho, que decorre da administração dos processos e do uso de equipamentos (prensa e coleta motorizada, notadamente).

Desta feita, em que pese o projeto não possuir ainda maiores informações quanto à sua aplicação, o objetivo do presente trabalho é a discussão abstrata do tema, uma vez que se entende que através deste modelo, ante a concretude de sua aplicação, o Pagamento por Serviços Ambientais Urbanos estaria mais voltado ao conceito de justiça ambiental.

No fundo, o sistema de serviços proposto pelo projeto de lei em tramitação no Município de Florianópolis é de extrema importância pois busca alcançar a justiça ambiental através da concessão de oportunidades e benefícios financeiros aos catadores e excluídos que, apesar de serem os que mais sofrem com os riscos iminentes da degradação do meio ambiente, protegem o ecossistema ao mesmo tempo que promovem a cidadania ambiental.

O que se pretende é apontar como ideia de pagamento do PSA o remanejamento fiscal de Fritjof Capra, utilizando-se do valor arrecadado com a Taxa de Coleta de Resíduos Sólidos - TCRS para o pagamento do benefício aos catadores, tendo em vista a diminuição que atingirem no contrato municipal de gestão dos resíduos.

No município de Florianópolis, a cobrança da TCRS se dá, desde 2016, de forma independente, separada do Imposto sobre Propriedade Predial e Territorial Urbana - IPTU, o que faz com que os valores arrecadados ingressem em uma conta específica, tornando claro qual o montante que ingressou nos cofres públicos oriundo da taxa.

67 ANDRADE, Marconi Tabosa de. Trabalho Economicamente Viável, Ambientalmente Sustentável, mas Socialmente Injusto. In: XV Encontro de Ciências Sociais Norte e Nordeste - Pré-ALAS Brasil, 2012, Teresina. Anais. Teresina: Universidade Federal do Piauí, 2012. 
SILVA, Carolina Schauffert Ávila da; LEITE, José Rubens Morato. Pagamento por Serviços Ambientais no contexto da Política Nacional de Resíduos: A Caso da Projeto de Lei de Florianópolis. Revista Eletrônica Direito e Política, Programa de Pós-Graduação Stricto Sensu em Ciência Jurídica da UNIVALI, Itajaí, v.13, n.1, $1^{\circ}$ quadrimestre de 2018. Disponível em: www.univali.br/direitoepolitica - ISSN 1980-7791

Uma vez que a TCRS tem como função primordial a gestão dos resíduos sólidos, sendo que os valores arrecadados devem ser direcionados para políticas públicas relacionadas à sua administração, pode caracterizar como a fonte para o pagamento do PSAU, garantindo segurança na concessão do benefício e o cumprimento dos deveres atinentes ao recurso público, quanto à sua finalidade.

\section{CONSIDERAÇÕES FINAIS}

A defesa do meio ambiente tem gerado forte influência no campo do Direito Econômico e Tributário, uma vez que se vê, em escala crescente, a ocorrência de uma verdadeira "ecologização" dos ramos, caracterizada por uma política ambiental voltada para a extrafiscalidade dos tributos

Neste sentido, fala-se em uma "política tributária conjuntural", que seria a capacidade do Direito se adaptar às políticas conjunturais econômicas, transformando-se em um dos mais importantes instrumentos de intervenção do Estado na economia. Verifica-se o protagonismo da interdisciplinaridade voltada à proteção ambiental, ante a importância do bem a ser tutelado, do qual depende a própria sobrevivência humana.

O ensaio objetivou trazer um enfoque teórico, reflexivo e proativo da proposta que objetiva a introdução de normas premiais, estabelecendo um instrumento fora do sistema tradicional da tutela administrativa de comando e controle, estabelecendo um instrumento econômico de pagamento por serviços ambientais voltados as pessoas vulneráveis da sociedade, como foco da política de resíduos a nível do âmbito local da Capital do Estado de Santa Catarina.

No âmbito das necessidades da crise ambiental local, bem como face aos objetivos de sustentabilidade planetária, são imprescindíveis novos caminhos para estímulo a uma política ambiental, visando rever e transformar o quadro atual da gestão ambiental do poder público, a transformação global, a mudança paradigmática e um novo sistema econômico, os quais são elementos básicos para trazer uma política de resíduos mais efetiva e eficaz, considerando as exigências da complexidade ambiental, do foco transdisciplinar, da visão sistêmica tendo em vista uma maior justiça ambiental. 
SILVA, Carolina Schauffert Ávila da; LEITE, José Rubens Morato. Pagamento por Serviços Ambientais no contexto da Política Nacional de Resíduos: A Caso da Projeto de Lei de Florianópolis. Revista Eletrônica Direito e Política, Programa de Pós-Graduação Stricto Sensu em Ciência Jurídica da UNIVALI, Itajaí, v.13, n.1, $1^{\circ}$ quadrimestre de 2018. Disponível em: www.univali.br/direitoepolitica - ISSN 1980-7791

Assim, urge voltar as preocupações para a busca de políticas de gestão que resultem em efeitos vistos na prática, com frutos concretos verificados na manutenção do meio ambiente.

E com esse objetivo primordial o presente trabalho analisou a interconexão entre a filosofia e o direito, buscando no modelo de remanejamento fiscal de Fritjof Capra a origem para a instituição do projeto de lei que tutele os serviços ambientais urbanos relacionados aos resíduos sólidos.

Através da função extrafiscal de tributos e da aplicação de normas indutoras no âmbito do direito ambiental, o projeto de lei apresentado surge como uma inovação na gestão de políticas públicas que adicionem u caráter social à preocupação ambiental, trazendo benefícios aos catadores e excluídos voltados a oportunidades de emprego e renda.

Desta forma, extrai-se da inovação legislativa existente no Brasil quanto à prioridade dada pela Lei de Políticas Públicas dos Resíduos Sólidos aos catadores para que sua forma de associação e trabalho sejam incentivados, incrementando a reciclagem de materiais descartados, diminuindo assim o uso dos recursos naturais.

Entende-se que a proposta de remanejamento fiscal é vantajosa e mais avançada para a melhoria da política de gestão de resíduos, pois propõe uma transformação de transição que tenta lidar com os problemas a partir da realidade do problema, propondo uma norma indutora e premial, fundada em inserção social de justiça ambiental, levando em conta a pré-compreensão da complexidade dos dilemas ambientais.

Para fazer face a um Estado de Direito mais Ecológico e eficaz na gestão ambiental temos que pensar em uma política ambiental local de resíduos mais proativa, saindo das regras tradicionais de comado e controle, impondo valor ao bem ambiental difuso dentro sistema econômico.

Assim, conclui-se que aplicação da extrafiscalidade nos resíduos sólidos como política de gestão ambiental dos Municípios pode trazer importantes resultados 
SILVA, Carolina Schauffert Ávila da; LEITE, José Rubens Morato. Pagamento por Serviços Ambientais no contexto da Política Nacional de Resíduos: A Caso da Projeto de Lei de Florianópolis. Revista Eletrônica Direito e Política, Programa de Pós-Graduação Stricto Sensu em Ciência Jurídica da UNIVALI, Itajaí, v.13, n.1, $1^{\circ}$ quadrimestre de 2018. Disponível em: www.univali.br/direitoepolitica - ISSN 1980-7791

quanto à produção de resíduos atualmente verificada, induzindo comportamentos aos resultados desejáveis para a manutenção do meio ambiente e de inclusão social, principalmente voltadas ao descarte destes dejetos, modelo já ambicionado por Fritjof Capra.

\section{REFERÊNCIAS DAS FONTES CITADAS}

(o) Eco. Disponível em <http://www.oeco.org.br/dicionario-ambiental/28158-oque-sao-servicos-ambientais/> Acesso em 21 de julho de 2017.

ALTVATER, Elmar. O preço da riqueza: pilhagem ambiental e a nova (des)ordem mundial. Tradução de Wolfgang Leo Maar. São Paulo: Unesp, 1995.

AMAZONAS, Maurício de Carvalho. Desenvolvimento Sustentável e a teoria econômica: o debate conceitual nas perspectivas neoclássica, institucionalista e da economia ecológica. In: NOBRE, Marcos; AMAZONAS, Maurício de Carvalho (org.) Desenvolvimento Sustentável: A institucionalização de um Conceito. Brasília: Edições IBAMA, 2002.

ANDRADE, Marconi Tabosa de. Trabalho Economicamente Viável, Ambientalmente Sustentável, mas Socialmente Injusto. In: XV Encontro de Ciências Sociais Norte e Nordeste - Pré-ALAS Brasil, 2012, Teresina. Anais. Teresina: Universidade Federal do Piauí, 2012.

BUGGE, Hans Christian. Twelve fundamental challenges in environmental law: an introduction to the concept of rule of law for nature. Rule of law for nature: New Dimensions and Ideas in Environmental Law. Cambridge University Press, 2013.

CAPRA, Fritjof. As conexões ocultas: ciência para uma vida sustentável. Tradução Marcelo Brandão Cipolla. Cultrix: São Paulo, 2002.

CARVAlHO, Paulo de Barros. Curso de direito tributário. 16. ed. São Paulo: Saraiva, 2011.

DALY, H. (ed). 1973. Toward a Steady-State Economy. W. H. Freeman, San Francisco. 
SILVA, Carolina Schauffert Ávila da; LEITE, José Rubens Morato. Pagamento por Serviços Ambientais no contexto da Política Nacional de Resíduos: A Caso da Projeto de Lei de Florianópolis. Revista Eletrônica Direito e Política, Programa de Pós-Graduação Stricto Sensu em Ciência Jurídica da UNIVALI, Itajaí, v.13, n.1, $1^{\circ}$ quadrimestre de 2018. Disponível em: www.univali.br/direitoepolitica - ISSN 1980-7791

DALY, H., 1984. Alternative strategies for integrating economics e ecology, in A.M. Jansson ed.,Integração of Economy e Ecology, Askö Laboratory, Universidade of Stockholm.

DAMÁSIO, J. Diagnóstico do entreposto de Itaboraí e efeitos sobre os demais entrepostos da Rede CataFlu. Relatório Final, Pangea; Fundação BB; Petrobrás, 2010.

Estudo da cadeia de comercialização de materiais recicláveis: uma pesquisa exploratória das estruturas de mercado das regiões metropolitanas de Salvador, São Paulo e Brasília. Relatório Final, Pangea; Fundação BB, 2010a.

DEMAJOROVIC J. A evolução dos modelos de gestão de resíduos sólidos e seus instrumentos. Cadernos FUNDAP; 1996.

DERZI, Misabel de Abreu Machado; COELHO, Sacha Calmon Navarro. Do Imposto sobre a propriedade predial e territorial urbana. São Paulo: Saraiva, 1982.

FAO-Organização das Nações Unidas para a Agricultura. Disponível em <http://www.fao.org/Es/esa/pesal> Acesso em 21 de julho de 2017.

FOLADORI, Guillermo. Limites do Desenvolvimento Sustentável. Campinas: Unicamp, 2001.

KOSOY, N. et al. Payments for environmental services in watersheds: insights from a comparative study of three cases in Central America. Ecological Economics, v. 61, n. 2, p. 446-455, 2007.

LEÃO, Martha Toribio. Controle da Extrafiscalidade - Série Doutrina Tributária v. XVI. São Paulo: Quartier Latin, 2015.

LEFF, Enrique. Discursos sustentáveis. Tradução de Silvana Cobucci Leite. São Paulo: Cortez, 2010. 
SILVA, Carolina Schauffert Ávila da; LEITE, José Rubens Morato. Pagamento por Serviços Ambientais no contexto da Política Nacional de Resíduos: A Caso da Projeto de Lei de Florianópolis. Revista Eletrônica Direito e Política, Programa de Pós-Graduação Stricto Sensu em Ciência Jurídica da UNIVALI, Itajaí, v.13, n.1, $1^{\circ}$ quadrimestre de 2018. Disponível em: www.univali.br/direitoepolitica - ISSN 1980-7791

LUSTOSA Peter H.; Maria Cecília; VINHA, Valéria da. (org.). Economia do Meio Ambiente. Rio de Janeiro: Elsevier, 2003.

MACHADO, Hugo de Brito. Curso de Direito Constitucional Tributário. $2^{\mathrm{a}}$ ed. São Paulo: Malheiros, 2015.

MARTINS, Giorgia Sena. Norma Ambiental: Complexidade e concretização. 2013. 411 p. Dissertação (Mestrado) - Universidade Federal de Santa Catarina, Centro Ciências Jurídicas, Programa de Pós-Graduação em Direito, Florianópolis, 2013. Disponível em: <http://www.bu.ufsc.br/teses/PDPC1106-D.pdf> Acesso em 22 de maio de 2017.

MELO, Melissa Ely. Pagamento por serviços ambientais (PSA): entre a proteção e a mercantilização dos serviços ecossistêmicos no contexto da crise ambiental. 2016. 492 p. Tese (Doutorado) - Universidade Federal de Santa Catarina, Centro de Ciências Jurídicas, Programa de Pós-Graduação em Direito, Florianópolis, $2016 . \quad$ Disponível em: <http://www.bu.ufsc.br/teses/PDPC1258-T.pdf>.

MONTERO, Carlos Eduardo Peralta. Tributação Ambiental: Reflexões sobre a introdução da variável ambiental no sistema tributário. São Paulo: Saraiva, 2014.

MONTEIRO, José Carlos Braga. A Relação da História da Humanidade e os Tributos. Disponível em http://www.portaltributario.com.br/artigos/relacao-dahistoria-humanidade-e-tributos.htm. 2014. Acesso em 23 de maio de 2017.

NUSDEO, Fabio. Curso de economia: introdução ao direito economico. São Paulo: Revista dos Tribunais, 1997.

OLIVEIRA, José Marcos Domingues. Tributação ambiental, tipicidade aberta e lançamento. Proporcionalidade e legalidade. Revista Forense. Rio de Janeiro: v. 93, n. 338, p. 125-135, abr./jun. 1997.

OliveIRA, R.; Horvath, E. Manual de direito financeiro. São Paulo: Ed. Revista dos Tribunais, 2002. 
SILVA, Carolina Schauffert Ávila da; LEITE, José Rubens Morato. Pagamento por Serviços Ambientais no contexto da Política Nacional de Resíduos: A Caso da Projeto de Lei de Florianópolis. Revista Eletrônica Direito e Política, Programa de Pós-Graduação Stricto Sensu em Ciência Jurídica da UNIVALI, Itajaí, v.13, n.1, $1^{\circ}$ quadrimestre de 2018. Disponível em: www.univali.br/direitoepolitica - ISSN 1980-7791

PAGIOLA, S.; ARCENAS, A.; PLATAIS, G. Can payments for environmental services help reduce poverty? An exploration of the issues and the evidence to date from Latin America. World Development, v. 33, n. 2, p. 237- 253, 2005.

PHILIPPI JR, A. Sistema de resíduos sólidos: coleta e transporte no meio urbano. 1979. Dissertação (Mestrado) Departamento de Saúde Ambiental da Faculdade de Saúde Pública da USP, São Paulo, 1979.

POPE, KAMILA. Understanding planned obsolescence: unsustainability through production, consumption na waste generation. London: Kogan Page Limited, 2017.

Relatório de Pesquisa sobre Pagamento por Serviços Ambientais Urbanos para Gestão de Resíduos Sólidos. Disponível em <http://www.mma.gov.br/estruturas/253/_arquivos/estudo_do_ipea_253.pdf> Acesso em 25 de julho de 2017.

Relatório de Pesquisa sobre Pagamento por Serviços Ambientais Urbanos para Gestão de Resíduos Sólidos. Disponível em <http://www.mma.gov.br/estruturas/253/_arquivos/estudo_do_ipea_253.pdf> Acesso em 25 de julho de 2017.

SCHOUERI, Luiz Eduardo. Normas Tributárias Indutoras e Intervenção Econômica. Rio de Janeiro: Forense, 2005.

SEVEN WUNDER apud SEVEN WUNDER et alli. Pagamento por Serviços Ambientais: Perspectivas para a Amazônia Legal. Brasília: MMA, 2009.

TROTTA, Pasquale. A gestão de resíduos sólidos em Portugal. Disponível em http://www.inovarse.org/sites/default/files/T11_0350_2173_7.pdf. Acesso em 03 de julho de 2017.

TUPIASSU, Lise Vieira da Costa. Tributação Ambiental: A utilização de instrumentos econômicos e fiscais na implementação do direito ao meio ambiente saudavel. Rio de Janeiro: Renovar, 2006. 
SILVA, Carolina Schauffert Ávila da; LEITE, José Rubens Morato. Pagamento por Serviços Ambientais no contexto da Política Nacional de Resíduos: A Caso da Projeto de Lei de Florianópolis. Revista Eletrônica Direito e Política, Programa de Pós-Graduação Stricto Sensu em Ciência Jurídica da UNIVALI, Itajaí, v.13, n.1, $1^{0}$ quadrimestre de 2018. Disponível em: www.univali.br/direitoepolitica - ISSN 1980-7791

Unidades de Conservação no Brasil. Disponível em <https://uc.socioambiental.org/servicos-ambientais/o-que-sao-servicosambientais> Acesso em 21 de julho de 2017.

VOIGT, Christina. The principle of sustainable development: integration and ecological integrity. Rule of law for nature: New Dimensions and Ideas in Environmental Law. Cambridge University Press, 2013.

WIKIPEDIA. Disponível em https://pt.wikipedia.org/wiki/Fritjof_Capra. Acesso em 03 de julho de 2017.

WUNDER, S. Payments for environmental services: some nuts and bolts. Bogor Barat: Cifor, 2005 (Cifor Occasional Paper, n. 42). Disponível em: $<$ http://www.cifor.cgiar.org/publications/pdf_files/OccPapers/OP-42.pdf>. Acesso em: 25 jul. 2017.

Submetido em: 08/02/2018

Aprovado em: 05/03/2018 